\title{
Upaya Meningkatkan Hasil Belajar Siswa Kelas VIII SMP Negeri 12 Banda Aceh Pada Pelajaran Pkn Materi Perlindungan Dan Penegakan Hak Azasi Manusia Melalui Penerapan Model Pembelajaran Kooperatif Tipe STAD
}

\author{
Sulastri, SH \\ SMP Negeri 12 Banda Aceh
}

\begin{abstract}
Abstrak
Penelitian ini bertujuan untuk meningkatkan prestasi belajar siswa pada mata pelajaran PKn. Metode penelitian yang digunakan adalah penelitian tindakan kelas (PTK) yang terdiri atas tiga siklus, setiap siklus terdiri dari dua kali pertemuan, setiap pertemuan terdiri dari empat tahap yaitu perencanaan, pelaksanaan, observasi dan refleksi. Subyek penelitian adalah siswa kelasVIII SMP Negeri 12 Banda Aceh tahun pelajaran 2018/2019 berjumlah 34 siswa. Analisis data menggunakan teknik analisis diskriptif komparatif dengan membandingkan kondisi awal dengan hasil-hasil yang dicapai pada setiap siklus, dan analisis deskriptif kualitatif hasil observasi dengan membandingkan hasil observasi dan refleksi pada siklus satu, siklus dua dan siklus tiga. Dari hasil tersebut penulis dapat mengambil kesimpulan bahwa implementasi model pembelajaran kooperatif tipe STAD sangat efektif dilakukan guna meningkatkan hasil belajar siswa SMP Negeri 12 Banda Aceh dalam pelajaran PKn materi perlindungan dan penegakan Hak Azasi Manusia, ini dapat dilihat dari hasil tes persiklus yaitu siswa yang dapat mencapai nilai KKM pada siklus I berjumlah 18 siswa (53\%), kemudian pada siklus II meningkat menjadi 25 siswa (74\%) dan pada siklus terakhir (siklus III) jumlah siswa yang dapat mencapai KKM meningkat menjadi 30 siswa (88\%).
\end{abstract}

Kata Kunci : Kooperatif, STAD, Hasil Belajar

\section{PENDAHULUAN}

Untuk menguasai dan menciptakan teknologi di masa depan diperlukan penguasaan PKN yang kuat sejak dini. Berdasarkan kurikulum pendidikan menengah adalah meningkatkan kecerdasan, pengetahuan, kepribadian, akhlak mulia, serta keterampilan untuk hidup mandiri dan mengikuti pendidikan lebih lanjut. Tidak lepas dari tujuan tersebut, PKN yang merupakan salah satu mata pelajaran pada pendidikan menengah atas mempunyai tujuan meningkatkan kecerdasan dalam berpikir logis, pengetahuan tentang PKN , keterampilan dalam berhitung dan syarat untuk mengikuti pendidikan lebih lanjut.

Tujuan tersebut menjadikan perlunya pelajaran PKN pada jenjang-jenjang pendidikan sekolah. Mata pelajaran PKN perlu diberikan kepada semua peserta didik mulai dari sekolah dasar untuk membekali peserta didik dengan kemampuan berpikir logis, analitis, sistematis, kritis, dan kreatif, serta kemampuan bekerjasama. Kompetensi tersebut diperlukan agar peserta didik dapat memiliki kemampuan memperoleh, mengelola, dan memanfaatkan informasi untuk bertahan hidup pada keadaan yang selalu berubah, tidak pasti, dan kompetitif.

Mata pelajaran PKN secara umum dipandang peserta didik sebagai pelajaran yang sulit sehingga tujuan pembelajaran yang sesuai dengan standar kompetensi tidak 
tercapai. Prestasi belajar peserta didik pada mata pelajaran PKN kurang memuaskan. Oleh karena itu diperlukan usaha untuk meningkatkan prestasi belajar PKN.

Salah satu upaya peningkatan prestasi belajar PKN adalah penggunaan metode pembelajaran yang tepat dengan materi pembelajaran yang diajarkan. Sebagai seorang guru harus dapat memilih metode pembelajaran yang cocok sehingga prestasi belajar peserta didik maksimal. Pembelajaran konvensional yang menggunakan metode ekspositori cocok diterapkan pada mata pelajaran PKN bahkan sub-sub materi pelajaran PKN . Tetapi guru perlu menggunakan variasi dalam mengajar yaitu menggunakan model pembelajaran atau metode pembelajaran yang lain sehingga model atau metode yang dipakai dapat memaksimalkan prestasi belajar PKN . Aspek yang dinilai dalam evaluasi mata pelajaran PKN pada jenjang pendidikan menengah atas adalah kognitif, afektif dan psikomotor.

Dengan kata lain aspek-aspek ini merupakan prestasi belajar yang hendak dicapai dalam pendidikan sekolah. Sejalan dengan kurikulum yang diberlakukan di sekolah, prestasi belajar PKN dapat ditingkatkan dengan menerapkan model pembelajaran yang efektif untuk meningkatkan prestasi belajar PKN . Dalam penelitian ini, prestasi belajar yang diteliti hanya aspek kognitif yaitu pemahaman konsep dan penalaran yang diukur dengan sebuah tes.

Aspek afektif dan psikomotorik tidak diteliti karena kemampuan dan keterbatasan peneliti, sedangkan untuk aspek pemecahan masalah tidak diteliti dan dievaluasikan karena pada ujian semester mata pelajaran PKN butir soal tentang materi pengertian otonomi daerah sebagian besar yang dievaluasi adalah pemahaman konsep dan penalaran. Dengan menerapkan model pembelajaran yang efektif meningkatkan pemahaman konsep dan penalaran peserta didik, prestasi belajar pada materi perlindungan dan penegakan hak azasi manusia dapat ditingkatkan.

Hasil observasi awal yang dilakukan peneliti diperoleh data bahwa hasil belajar peserta didik kelas VIII terhadap pembahasan perlindungan dan penegakan hak azasi manusia masih banyak yang kurang baik, masih di bawah Kriteria Ketuntasan Minimal (KKM). Peserta didik lebih cenderung menghafal dari pada memahami materi dan masih ada juga peserta didik yang menganggap perlindungan dan penegakan hak azasi manusia itu sulit sehingga motivasi belajarnya kurang. Karena prestasi belajar PKN peserta didik kelas VIII pada SMP Negeri 12 Banda Aceh pada semester genap kurang memuaskan maka guru perlu mengubah model pembelajaran dan menggunakan variasi metode pembelajaran lain yang lebih efektif untuk meningkatkan prestasi belajar PKN pada materi perlindungan dan penegakan hak azasi manusia.

Pembelajaran PKn di Kelas VIII pada SMP Negeri 12 Banda Aceh Semester II Tahun Pelajaran 2018-2019, Berdasarkan catatan guru, aktivitas siswa dalam tanya jawab dan diskusi kelas masing-masing hanya sebesar 40\% dan 35\% dari 32 siswa yang ada. Sebagian besar dari siswa justru memperlihatkan aktivitas yang tidak relevan dengan pembelajaran, seperti kelihatan bengong dan melamun, kurang bergairah, kurang memperhatikan, bermain-main sendiri, berbicara dengan teman ketika dijelaskan, canggung berbicara atau berdialog dengan teman waktu diskusi. Sementara itu dari hasil ulangan harian prestasi belajar mereka hanya sebesar $45 \%$ yang berhasil mencapai batas KKM. Padahal KKM yang ditetapkan bagi Kelas VIII pada SMP Negeri 12 Banda Aceh Tahun Ajaran 2018-2019 untuk mata pelajaran PKn adalah sebesar 65 
Salah satu upaya untuk mengatasi persoalan tersebut adalah dengan menggunakan model pembelajaran kooperatif tipe STAD dalam proses pembelajaran khususnya dalam materi perlindungan dan penegakan hak azasi manusia. Dengan adanya pembelajaran kelompok kecil peserta didik dapat lebih aktif dan bekerja dalam kelompok kecil untuk mendapatkan pengetahuan baru. Dengan meningkatnya keaktifan peserta didik, diharapkan meningkat pula motivasi belajar sehingga prestasi belajar peserta didik menjadi lebih baik dan dicapai hasil yang maksimal.

\section{Tujuan Penelitian}

Penelitian ini bertujuan untuk meningkatkan prestasi belajar siswa pada mata pelajaran PKn.

\section{KAJIAN TEORI}

\section{Pengertian Pembelajaran Kooperatif}

Teori yang melandasi pembelajaran kooperatif adalah teori konstruktivisme. Pada dasarnya pendekatan teori konstruktifisme dalam belajar adalah suatu pendekatan di mana siswa secara individu menemukan dan mentranseformasikan imformasi yang kompleks, memeriksa imformasi dengan aturan yang dan merivisinya bila perlu (soejadi dalam teti sobri,2006. 15).

Menurut Slavin (2007), pembelajaran kooperatif menggalakan siswa berinteraksi secara aktif dan positif dalam kelompok. Ini membolehkan poertukaran ide dan pemeriksaaan ide sendiri dalam suasana yang tidak terancam, sesuai dengan falsafah konstruktivisme. Dengan demikian, pendidikan hendaknya mampu menggkondisikan dan memberikan dorongan untuk dapat mengoptimalkan dan membangkitkan potensi siswa, menumbuhkan aktifitas dan daya cipta kreativitas sehingga akan menjamin terjadinya dinamika di dalam proses pemebelajaran.

Dalam teori konstruktivisme ini lebih mengutamakan pada pembelajaran siswa yang dihadapkan masalah-masalah komplek untuk di cari solusinya, selanjutnya menemukan bagian-bagian yang lebih sederhana dan keterampiulan yang diharapkan. Model pembelajaran ini dikembangkan dari teori belajar konstruktivisme yang lahir dari gagasan Piaget dan Vygotsky. Berdasarkan penelitian Piaget yang pertama dikemukakan bahwa pengetahuan itu dibangun dalam pikiran anak (Ratna, 1988: 181)

Dalam model pemebelajaran kooperatif ini guru berpesan sebagai fasilitator yang berfungsi sebagai jembatan penghubungan ke arah pemahaman yang lebih tinggi, dengan catatan siswa sendiri. Guru tidak hanya memberikan pengetahuan pada siswa, tetapi harus juga membangun dalam pikirannya. Siswa mempunyai kesempatan untuk mendapatkan pengetahuan langsung dalam menerapkan ide-ide meraka, ini merupakan kesempatan bagi siswa untuk menemukan dan menerapkan ide-ide mereka sendiri.

Piaget dan Vygotsky mengemukakan adanya hakikat sosial dari sebuah proses belajar dan juga mengemukakan tentang penggunaan kelompok-kelompok belajar dengan kkemapuan anggota-anggotanya yang beragam sehingga terjadi perubahan konseptual. Piaget menekankan bahwa belajar adalah sebuah proses aktif dan pengetahuan disususn dalam pemikiran siswa. Oleh karena itu, belajar adalah tindakan kreatif di mana konsep dan kesan dibentuk dengan memikirkan objek dan peristiwa serta beraksi dengan objek dan peristiwa tersebut. 
Di samping aktivitas dan kreativitas yang diharapkan dalam sebuah proses pembelajaran, dituntut interaksi yang seimbang. Interaksi yang dimaksud adalah adanya interaksi atau komunikasi antara guru dengan siswa, siswa dengan siswa. Guru dengan siswa, diharapkan dalam proses belajar terdapat komunikasi banyak arah, yang memungkinkan banyak arah, yang memungkinkan akan terjadi aktivitas, kreativitas yang diharapkan. Pandangan konstruktivitasme Piaget dan Vygotsky dapat berjalan berdampingan dalam proses pembelajaran konstruktivisme.

Piaget yang menekankan pada kegiatan internal individu terhadap objek yang dihadapi dan pengalaman yang dimiliki orang tersebut, sedangkan konstruktivisme Vygotsky menekankan pada intraksi sosial dan melakukan konstruksi pengetahuan dari lingkungan sosialnya. Berkaitan dengan karya Vygotsky dan penjelasan Piaget, para konstruktivis menekankan pentinya interaksi dengan teman sebaya melalui pembentukan kelompok belajar, siswa diberikan kesempatan secara aktif untuk mengungkapkan sesuatu yang dipikirkan kepada temannya, hal itu akan membantunya untuk melihat sesuatu dengan jelas , bahkan melihat ketidaksesuaian pandangan mareka sendiri.

\section{Konsep Dasar Pembelajaran Kooperatif}

Pembelajaran kooperatif (cooperatf learning) merupakan bentuk pembelajaran dengan cara siswa belajar dan bekerja dalam kelompok- kelompok kecil secara kolaboratif yang anggotanya terdiri dari empat sampai dengan enam orang dengan struktur kelompok yang bersifat Heterogen. Pada hakekatnya coopertaif learning sama dengan kerja kelompok. Oleh karena itu banyak guru yang menyatakan tidak ada sesuatu yang aneh dalam kooperatif learning karena mereka telah biasa melakukan pembelajaran kooperatif learning dalam bentuk belajar kelompok, walaupun tidak semua berakar kelompok disebut dalam kooperatif learning seperti dijelaskan oleh Abdulhak (2001: 19-20) " pembelajaran kooperatif dilaksanakan melalui shering proses antara peserta didik sehingga dapat mewujudkan pemahaman bersama antara peserta didik itu sendiri."

Dalam pembelajaran ini akan tercipta sebuah interaksi yang lebih luas, yaitu interaksi dan komunikasi antara guru dengan siswa, siswa dengan siswa, dan siswa dengan guru (multi way traffic communication). Pembelajaran kooperatif adalah starategi pembelajaran yang melibatkan partisispasi siswa dalam suatu kelompok kecil untuk saling berinteraksi “. (Nurhayati,2002 : 25). Dalam sistem belajar yang kooperatif siswa belajar bekerjasama dengan anggota lainnya. Dalam model ini siswa memiliki dua tanggung jawab, yaitu mereka belajar untuk dirinya sendiri, dan membantu sesama anggota untuk belajar. Siswa dapat belajar dalam kelompok kecil dan dapat melalukannya seorang diri.

Cooperatif learning adalah merupakan kegiatan belajar siswa dengan cara berkelompok. Model pembelajaran kelompok adalah rangkaian kegiatan belajar yang dilakukan oleh siswa dalam kelompok-kelompok tertentu untuk mencapai tujuan yang telah dirumuskan. (Sanjaya 2006.: 239) Tom V. Savage (1987:25) mengemukakan bahwa "cooperative learning merupakan satu pendekatan yang menekankan kerja sama dalam kelompok pembelajaran kooperatif adalah stategi pembelajaran yang melibatkan partisipasi siswa dalam suatu kelompok kecil untuk saling berinteriaksi”. 
Dalam sistem belajar kooperatif siswa belajar bekerja bersama anggota lainnya. (Nurul hayati. 2002:25) Pembelajaran kooperatif tidak sama dengan sekedar belajar dalam bentuk kelompok. Ada unsur dasar pemebelajaran kooperatif yang membedakan dengan pembelajaran kelompok yang asal-asalan . Pelaksanaan prinsip dasar pokok system pembelajaran kooperatif dengan benar akan memungkinkan guru mengelola kelas dengan lebih efektif. Dalam pembelajaran kooperatif proses pembelajaran tidak harus bejalan dari guru kepada siswa, siswa dapat belajar dari siswa lainnnya. Karena pembelajaran oleh rekan sebaya lebih efektif dari pembelajaran oleh guru.

Koperatif learning adalah teknik pengelompokan yang di dalamnya siswa bekerja terarah pada tujuan belajar bersama dengan kelompok kecil yang umumnya terdiri dari 4-5 orang siswa. Belajar kooperatif adalah belajar pemanfaatan kelompok kecil dalam pembelajaran yang memungkinkan siswa bekerja sama untuk memaksimalkan belajar mereka dan belajar anggota lainnya dalam kelompok tersebut (Jonson Dalam Hasan. 1996).

Terdapat enam langkah utama atau tahapan di dalam pelajaran yang menggunakan pembelajaran kooperatif, pembelajaran dimulai dari guru menyampaikan tujuan pembelajaran dan memotivasi siswa untuk belajar. Fase ini digunakan untuk menyampaikan informasi, sering bahan bacaan dari pada verbal. Selanjutnya, siswa di kelompokan dalam tim-tim belajar. Tahapan ini diikuti bimbingan guru pada saat siswa bekerja bersama untuk menyelesaikan tugas bersama mereka, fase terahir pemebelajaran kooperatif adalah meliputi presentasi hasil kerja kelompok, atau evaluasi tentang apa yang telah mereka pelajari dan memberikan penghargaan terhadap usahausaha kelompok maupun individu.

Berikut dapat dilihat langkah-langkah model pembelajaran kooperatif

\begin{tabular}{|l|l|}
\hline \multicolumn{1}{|c|}{ Tahap } & \multicolumn{1}{c|}{ Aktivitas Guru } \\
\hline $\begin{array}{l}\text { Tahap 1 } \\
\text { Menyampaikan Tujuan } \\
\text { dan } \\
\text { Memotivasi siswa }\end{array}$ & $\begin{array}{l}\text { Guru menyampaikan tujuan pembelajaran yang } \\
\text { akan dicapai pada kegiatan pembelajaran dan } \\
\text { menekankan pentingnya topic yang akan } \\
\text { dipelajari dan memotivasi siswa belajar. }\end{array}$ \\
\hline $\begin{array}{l}\text { Tahap 2 } \\
\text { Menyajikan Informasi }\end{array}$ & $\begin{array}{l}\text { Guru menyajikan imformasi atau materi kepada } \\
\text { siswa dengan jalan demonstrasi atau melalui } \\
\text { bahan bacaan }\end{array}$ \\
\hline $\begin{array}{l}\text { Tahap 3 } \\
\text { kengorganisasikan siswa dalam kelompok - } \\
\text { kelompok belajar }\end{array}$ & $\begin{array}{l}\text { Guru menjelaskan kepada siswa bagaimana } \\
\text { caranya membentuk kelompok belajar dan } \\
\text { membimbing setiap kelompok agar melakukan } \\
\text { transisi secara efektif dan efisien }\end{array}$ \\
\hline $\begin{array}{l}\text { Tahap 4 } \\
\text { Membimbing kelompok } \\
\text { bekerja dan belajar }\end{array}$ & $\begin{array}{l}\text { Guru membimbing kelompok-kelompok belajar } \\
\text { pada satu mereka mengerjakan tugas mereka. }\end{array}$ \\
\hline $\begin{array}{l}\text { Tahap 5 } \\
\text { Evaluasi }\end{array}$ & $\begin{array}{l}\text { Guru mengevaluasi hasil belajar tentang materi } \\
\text { yang telah dipelajari atau masing- masing } \\
\text { kelompok mempersentasikan hasil kerjanya }\end{array}$ \\
\hline $\begin{array}{l}\text { Tahap 6 } \\
\text { Memberikan penghargaan }\end{array}$ & $\begin{array}{l}\text { Guru mencari cara-cara untuk menghargai baik } \\
\text { upaya maupun hasil belajar individu dan } \\
\text { kelompok }\end{array}$ \\
\hline
\end{tabular}




\section{METODE}

\section{Tempat dan Waktu Penelitian}

Penelitian tindakan kelas ini berlangsung di kelas VIII pada SMP Negeri 12 Banda Aceh pada semester II tahun ajaran 2018-2019. Proses penyusunan laporan karya tulis ini di laksanakan pada semester II dalam kurun waktu dua bulan Yaitu maret sampai dengan april.

\section{Populasi dan Sampel}

Subyek penelitian tindakan kelas ini adalah siswa-siswi kelas VIII pada SMP Negeri 12 Banda Aceh yang berjumlah 34 siswa atau siswi terdiri dari 13 siswa lakilaki dan 22 orang siswa perempuan.

Sumber data pada penelitian tindakan kelas ini yang diperoleh dari siswa atau siswi kelas XI, dewan guru serta kepala sekolah SMP Negeri 12 Banda Aceh

\section{HASIL PENELITIAN DAN PEMBAHASAN Pelaksanaan Siklus I}

Siklus I dilaksanakan dalam dua kali pertemuan yaitu tanggal 21 Maret 2019 (pertemuan pertama) dan tanggal 28 Maret 2019 dikelas VIII SMP Negeri 12 Banda Aceh.

\section{Perencanaan}

- Kegiatan-kegiatan yang dilakukan pada tahap ini meliputi:

- Identifikasi masalah dan penetapan alternatif pemecahan masalah;

- Merencanakan pembelajaran yang akan diterapkan dalam proses belajar mengajar;

- Menetapkan standar kompetensi dan kompetensi dasar;

- Memilih bahan pelajaran yang sesuai;

- Menentukan skenario pembelajaran sesuai dengan pendekatan yang telah dipilih yaitu model pembelajaran ooperati tipe STAD

- Mempersiapkan sumber, bahan, dan alat bantu yang dibutuhkan;

- Menyusun lembar kerja siswa;

- Menyusun format observasi;

- Mengembangkan format evaluasi;

\section{Tindakan}

Kegiatan pada tahap ini merupakan pelaksanaan tindakan perbaikan dalam kegiatan pembelajaran sesuai dengan pendekatan yang dipilih dan dengan mengacu pada skenario pembelajaran yang telah direncanakan, Berikut langkah-langkah pembelajaran :

\section{Pertemuan Ke 1}

Pendahuluan 
- Apersepsi

- Mempersiapkan kelas dalam pembelajaran

- Memotivasi

- Melakukan penjajakan kesiapan belajar siswa dengan memberikan pertanyaan tentang materi yang akan diajarkan.

- Memberikan informasi tentang kompetensi yang akan dicapai.

- Siswa membentuk kelompok kecil beranggotakan 5 orang yang dibentuk secara acak sesuai arahan dari guru sesuai dengan model pembelajaran kooperatif tipe STAD

Kegiatan Inti

Eksplorasi

- Penjelasan konsep secara umum tentang arti/pengertian HAM yang ada dalam NKRI dikaitkan dengan HAM yang ada di sekitar tempat tinggal siswa.

\section{Elaborasi}

- Melakukan kajian pustaka dengan menelaah UUD 1945 pada Pasal 28A sampai $28 \mathrm{~J}$.

- Membagi siswa dalam 8 kelompok.Menginstruksikan siswa untuk berdiskusi setelah mendengar dan menelaah tentang UUD 1945 pasal 28A sampai dengan 28J.Konfirmasi

- Guru meminta pendapat siswa tentang pengertian HAM dan UUD 1945 pada pasal 28A.Setelah selesai, masing-masing kelompok melakukan presentasi hasil diskusi.

\section{Penutup}

a. Dengan bimbingan guru, siswa menyimpulkan hasil diskusi.

b. Melakukan tindak lanjut dengan memberi tugas untuk mempersiapkan diskusi minggu berikutnya dengan membuat resume tentang pengertian HAM, UUD 1945, dan UU No. 39 Tahun 1999 dan Undang-Undang No. 23 tahun 2002.

\section{Pertemuan Ke 2}

\section{Pendahuluan}

- Apersepsi

- Mempersiapkan kelas dalam pembelajaran

- Memotivasi

- Melakukan penjajakan kesiapan belajar siswa dengan memberikan pertanyaan tentang materi yang akan diajarkan.

- Memberikan informasi tentang kompetensi yang akan dicapai.

\section{Kegiatan Inti}

Eksplorasi

- Menjelaskan konsep tentang pentingnya mengerti dan memahami hak asasi.

\section{Elaborasi}

- Melakukan kajian pustaka tentang hak-hak anak yang tercantum dalam UndangUndang No. 39 Tahun 1999 dan Undang-Undang No. 23 Tahun 2002 tentang Perlindungan Anak. 
- Membagi siswa dalam 8 kelompok dan mendiskusikan hak-hak anak.

- Mempresentasikan hasil diskusi

\section{Penutup}

Adapun kegiatan penutup

a. Guru dan siswa menyimpulkan materi yang dibahas.

b. Memberikan test

c. Melakukan tindak lanjut dengan memberi tugas rumah untuk mempersiapkan materi yang akan datang dengan membaca dan menelaah buku-buku PKn dengan kajian pustaka

\section{Pengamatan (Observasi )}

Teknik pelaksanaan pengamatan ini dilakukan dengan menggunakan format observasi terstruktur yang telah disiapkan sebelumnya, yaitu berupa tabel-tabel isian untuk setiap aspek pengamatan dari aktivitas belajar siswa. Hasil pengamatan penulis pada siklus I ini ditemukan bahwa :

Guru belum maksimal dalam menguasai model pembelajaran kooperatif tipe STAD, ini terlihat dari tidak terkontrolnya siswa dalam proses belajar mengajar, sebagian siswa masih tidak memperhatikan penjelasan guru, siswa asik ribut dan mengganggu teman bahkan ada beberapa siswa yang minta izin keluar kelas dengan berbagai alasan dan juga masih ada siswa tidak konsen mengikuti pembelajaran karena mengantuk (bosan mengikuti pelajaran).

Hasil obeservasi juga di ketahui bahwa pembelajaran yang dilakukan guru masih belum sesuai dengan perencanaan awal (RPP) sehingga indikator pada siklus I ini belum dapat dicapai, meskipun demikian hasil observasi yang dilakukan terlihat adanya peningkatan dari aktivitas dan hasil belajar siswa dibandingkan dengan observasi awal (prasiklus) yang dilakukan peneliti. Untuk lebih jelas dapat dilihat pada tabel dibawah ini :

Tabel Data Aktivitas Belajar Siswa Siklus I

\begin{tabular}{|c|l|c|c|}
\hline No & \multicolumn{1}{|c|}{ Indikator Proses } & $\begin{array}{c}\text { Jumlah } \\
\text { Siswa }\end{array}$ & $\begin{array}{c}\text { Persentas } \\
\text { e (\%) }\end{array}$ \\
\hline 1 & $\begin{array}{l}\text { Keberanian siswa dalam bertanya dan } \\
\text { mengemukakan pendapat }\end{array}$ & 22 & 65 \\
\hline 2 & $\begin{array}{l}\text { Motivasi dan kegairahan dalam proses belajar } \\
\text { (meyelesaikan tugas mandiri atau tugas } \\
\text { kelompok) }\end{array}$ & 22 & 65 \\
\hline 3 & Kerjasama dalam kelompok & 21 & 62 \\
\hline 4 & $\begin{array}{l}\text { Kreativitas belajar siswa (membuat catatan, } \\
\text { ringkasan) }\end{array}$ & 20 & 59 \\
\hline 5 & $\begin{array}{l}\text { Interaksi dan komunikasi dengan sesama siswa } \\
\text { selama pembelajaran (dalam kerja kelompok) }\end{array}$ & 20 & 59 \\
\hline 6 & $\begin{array}{l}\text { Interaksi dan komunikasi dengan guru selama } \\
\text { kegiatan pembelajaran }\end{array}$ & 19 & 56 \\
\hline 7 & $\begin{array}{l}\text { Partisipasi siswa dalam } \\
\text { pembelajaran (memperhatikan dan } \\
\text { mendengarkan, ikut melakukan kegiatan }\end{array}$ & 19 & \\
\hline
\end{tabular}




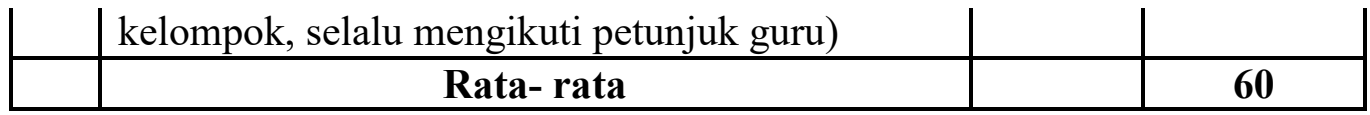

Berdasarkan data dari tabel di atas penulis dapat menjelaskan bahwa hasil observasi guru terhadap aktivitas siswa pada saat proses belajar mengajar berlangsung dengan menggunakan lembar observasi aktivitas siswa, yaitu sebesar 60\% dari 34 jumlah siswa keseluruhannya. Hal ini menunjukkan bahwa aktivitas siswa masih tergolong dalam kategori rendah. Untuk itu perlu dilakukan perbaikan pada pelaksanaan siklus berikutnya.

Guru harus maksimal lagi dalam melaksanakan pembelajaran dengan model pembelajaran kooperatif tipe STAD, RPP harus benar-benar menjadi panduan dalam pembelajaran sehingga indikator pembelajaran dapat tercapai.

Tabel Data aktivitas siswa yang kurang relevan dengan pembelajaran Siklus I

\begin{tabular}{|c|c|c|c|}
\hline No & Indikator Proses & $\begin{array}{l}\text { Jumlah } \\
\text { Siswa }\end{array}$ & $\begin{array}{l}\text { Persentase } \\
(\%)\end{array}$ \\
\hline 1 & Asik bermain sendiri & 14 & 41 \\
\hline 2 & $\begin{array}{l}\text { Tidak/kurang memperhatikan penjelasan dari } \\
\text { guru atau teman sekelas }\end{array}$ & 14 & 41 \\
\hline 3 & Mengobrol dan bercanda sendiri dengan teman & 13 & 38 \\
\hline 4 & Melamun dan kurang bergairah belajar & 13 & 38 \\
\hline 5 & Mengerjakan tugas pelajaran lain & 14 & 41 \\
\hline & Rata- rata & & 40 \\
\hline
\end{tabular}

Berdasarkan data pada tabel di atas terlihat bahwa aktivitas siswa yang kurang relevan dengan kegiatan pembelajaran masih tinggi yaitu sebesar $40 \%$ dari 34 jumlah siswa keseluruhan.

Tabel Data Hasil Belajar Siswa Siklus I

\begin{tabular}{|c|c|c|c|c|c|}
\hline No & $\begin{array}{c}\text { Hasil } \\
\text { (angka) }\end{array}$ & $\begin{array}{c}\text { Hasil } \\
\text { (huruf) }\end{array}$ & $\begin{array}{c}\text { Arti } \\
\text { Lambang }\end{array}$ & $\begin{array}{c}\text { Jumlah } \\
\text { Siswa }\end{array}$ & $\begin{array}{c}\text { Persentase } \\
(\%)\end{array}$ \\
\hline 1 & $86-100$ & $\mathrm{~A}$ & Sangat baik & 0 & 0 \\
\hline 2 & $71-85$ & B & Baik & 17 & 50 \\
\hline 3 & $65-70$ & $\mathrm{C}$ & Cukup & 1 & 3 \\
\hline 4 & $41-64$ & $\mathrm{D}$ & Kurang & 16 & 47 \\
\hline 5 & $<40$ & $\mathrm{E}$ & Sangat kurang & 0 & 0 \\
\hline \multicolumn{4}{|c|}{ Jumlah } & 34 & $100 \%$ \\
\hline
\end{tabular}

Berdasarkan table menunjukkan bahwa yang jumlah yang mendapat nilai sangat baik (86-100) adalah tidak ada (0\%), yang mendapat nilai baik (75-85) berjumlah 17 orang (50\%), yang mendapat nilai cukup (65-70) berjumlah 1 orang (3 $\%)$, yang mendapat nilai kurang (50-64) berjumlah 16 orang (47\%) dan siswa yang mendapat nilai sangat kurang $(<49)$ tidak ada $(0 \%)$.

Tabel Data Ketuntasan Belajar Siswa Siklus I

\begin{tabular}{|c|l|c|c|}
\hline \multirow{2}{*}{ No } & \multirow{2}{*}{ Ketuntasan } & \multicolumn{2}{|c|}{ KKM 65 } \\
\cline { 2 - 4 } & & Jumlah & Persentase (\%) \\
\hline $\mathbf{1}$ & Tuntas & 18 & 53 \\
\hline $\mathbf{2}$ & Tidak tuntas & 16 & 47 \\
\hline \multicolumn{2}{|c|}{ Jumlah } & $\mathbf{3 4}$ & $\mathbf{1 0 0}$ \\
\hline
\end{tabular}


Berdasarkan tabel di atas penulis dapat didiskripsikan bahwa persentase ketuntasan belajar siswa masih sangat jauh dari KKM minimal yang direncanakan yaitu berjumlah 18 orang $(53 \%)$ dari 34 jumlah siswa keseluruhan sedangkan yang tidak tuntas berjumlah 16 siswa ( $47 \%$ )

\section{Refleksi}

Tahap ini merupakan evaluasi atas tindakan yang telah dilakukan, tindakan mana yang sudah berhasil sesuai dengan rencana dan mana yang perlu diperbaiki sebagai acuan untuk menyusun rencana tindakan pada siklus kedua. Dan berikut dapat dilihat hasil evaluasi pada siklus I :

1. Pada siklus ini guru terlalu dominan dalam kelas sehingga siswa terlihat pasif dan kurang mengemukakan pendapat terhadap materi yang dibahas, siswa rata-rata hanya mendengarkan saja.

2. Penguasaan terhadap model pembelajaran tidak maksimal, terlihat kaku dan ini menyebabkan siswa sulit terkontrol sehingga hasil pembelajaran tidak sesuai dengan apa yang direncanakan.

3. Pengelolaan waktu tidak maksimal, guru melaksanakan proses pembelajaran tidak sesuai dengan RPP yang dibuat.

\section{KESIMPULAN}

Simpulan utama yang dihasilkan dalam penelitian tindakan kelas ini merupakan jawaban terhadap masalah penelitian yang telah dirumuskan, yaitu Penerapan model pembelajaran kooperatif tipe STAD dapat meningkatkan aktivitas belajar siswa pada mata pelajaran PKn materi perlindungan dan penegakan hak azasi manusia terhadap siswa kelas VIII SMP Negeri 12 Banda Aceh tahun ajaran 2018-2019 sebesar 27\% (dari semula $60 \%$ pada siklus I menjadi $87 \%$ pada akhir siklus III). Penerapan model pembelajaran kooperatif tipe STAD dapat meningkatkan hasil belajar siswa pada mata pelajaran PKn materi perlindungan dan penegakan hak azasi manusia, yaitu meningkat sebesar 52\% (dari semula $36 \%$ yang yang tuntas pada siklus I meningkat menjadi $88 \%$ pada akhir siklus III) dari prestasi belajar atau ketuntasan belajar siswa Kelas VIII di Semester II pada SMP Negeri 12 Banda Aceh Tahun Ajaran 2018-2019. Dengan demikian maka tindakan guru dalam menerapkan model pembelajaran kooperatif tipe STAD pada bidang studi PKn di sini telah berhasil dalam mencapai tujuan yang diinginkan.

\section{DAFTAR PUSTAKA}

Arikunto, Suharsimi, Suhardjono, dan Supardi. 2006. Penelitian Tindakan Kelas. Jakarta: Bumi Aksara

A. Tabrani Rusyan dkk (1993). Pendekatan Dalam Proses Belajar Mengajar. Bandung : Sinar Baru Algesindo

Arsyad, A. (2011). Media Pembelajaran. Jakarta: Rajawali Pers.

Aunurrahman. (2010). Belajar dan Pembelajaran. Bandung : Penerbit

Alfabeta, Slameto. (2003). Belajar dan Faktor-Faktor yang Mempengaruhinya. Jakarta: PT. Rineka Cipta.

Al-Ghazali 2001. dalam Slameto. 2003. Strategi Belajar Mengajar. Jakarta.

Budimansyah Dasim. 2002. Metode Pembelajaran dan Penilaian. Siliwangi. HDB 
Dimyati dan Mudjiono, 1992. Strategi Belajar Mengajar. Jakarta. Depdikbud.

Hilgard dalam Slameto 2003 Strategi Belajar Mengajar. Jakarta

Slameto. 2003. Belajar dan Faktor-faktor Yang Mempengaruhinya. Jakarta

Selamat Santosa ( 2009 ). Pendidikan Kewarganegaraan kelas 7 SMP / Mts . Jakarta

Syaiful Bahri Djamarah. 2000. Prestasi Belajar Dan Kompetensi Guru. Surabaya: Usaha Nasional.

Sagala, Syaiful. 2010. Konsep dan Makna Pembelajaran. Bandung: ALFABETA.

Oemar Hamalik.1993. Metode Mengajar dan Kesulitan-Kesulitan Belajar. Bandung: Tarsito.

Palendeng. 2003. Model pembelajaran kooperatif tipe STAD dalam Pembelajaran. http:archive. Blog Pendidikan .Com

Udin Syaefuddin, dkk (2006) pembelajaran terpadu. Bandung: UPI Press

Roestiyah (2001). Strategi Belajar Mengajar. Jakarta : Rineka Cipta 